\title{
Experimental study on energy consumption in the plasticizing unit of the injection molding machine
}

\author{
Jacek Iwko ${ }^{1) * *)}$, Roman Wroblewski ${ }^{1)}$, Ryszard Steller ${ }^{2)}$ \\ DOI: dx.doi.org/10.14314/polimery.2018.5.5
}

\begin{abstract}
In this work the energy needed for reciprocating screw motion and heating of the barrel were examined by changing various parameters of the injection molding process, measuring the process characteristics and calculating the corresponding values of SEC (specific energy consumption). Five thermoplastic polymers were examined. It was found that the optimal condition from the energy consumption point of view to perform the plasticization of thermoplastic polymers on the research position is low value of rotational velocity of the screw. Furthermore, an increase of the SEC value with increasing barrel temperature was shown. It was also found that changes of back pressure do not affect the energy consumption of the plasticizing system of the injection molding machine.
\end{abstract}

Keywords: injection molding, plasticization, plastics, energy consumption, specific energy consumption.

\section{Badania doświadczalne zużycia energii w układzie uplastyczniającym wtryskarki}

Streszczenie: Badano zużycie energii potrzebnej na wykonanie ruchu posuwisto-obrotowego ślimaka oraz ogrzewanie cylindra $\mathrm{w}$ procesie wtryskiwania prowadzonym $\mathrm{w}$ zmiennych warunkach procesowych. Dokonano pomiaru charakterystyk wyjściowych procesu wtryskiwania oraz wyznaczono na ich podstawie wartości SEC (jednostkowego zużycia energii). Przetwarzano pięć typowych polimerów termoplastycznych. Stwierdzono, że mała prędkość obrotowa ślimaka zapewnia optymalne, ze względu na niewielkie zużycie energii, warunki do prowadzenia procesu wtryskiwania na analizowanym stanowisku badawczym. Wykazano ilościowy wpływ wzrostu temperatury cylindra na wartość SEC, a także brak wpływu zmiany ciśnienia uplastyczniania na zużycie energii przez układ uplastyczniający wtryskarki.

Słowa kluczowe: wtryskiwanie, uplastycznianie, polimery, zużycie energii, jednostkowe zużycie energii.

Energy consumption is one of the most important parameters associated with the analysis of technological processes. Energy efficiency of technological processes is one of the critical issues for the manufacturing industry, mainly due to increasing cost of energy and the impact on the environment. Reducing energy consumption is therefore relevant not only for the economic benefits to producers, but also because of the improving of environmental performance of the products manufacture [1-7]. This can be done only with precise knowledge of the production process and its energy characteristics, as

\footnotetext{
1) Wroclaw University of Technology, Faculty of Mechanical Engineering, Department of Foundry, Plastics and Automation, Wybrzeże Wyspianskiego 27, 50-370 Wroclaw, Poland.

2) Wroclaw University of Technology, Faculty of Chemistry, Department of Polymer Engineering and Technology, Wybrzeże Wyspianskiego 27, 50-370 Wroclaw, Poland.

*) Author for correspondence; email: jacek.iwko@pwr.edu.pl
}

well as knowledge of effect of processing parameters on energy consumption per mass unit (called SEC - specific energy consumption).

Injection molding of plastic is now one of the most widely used manufacturing processes. With this technique, millions of parts of various types and sizes, ranging from electronic and electrical components, toys, packaging, through elements of automobile and pharmaceutical industry, to precise microdetails for technology or medicine are produced. Injection molding process is often preferred by designers because of the possibility of applying different polymeric materials and very short process time, as well as the repeatability and accuracy of obtained products. Although polymer materials are characterized by substantial value of SEC at their production stage [8] (Fig. 1), the energy consumption of manufacturing processes of polymeric materials per unit volume of product are extremely low in comparison with other processes [9]. This issue indicates that polymers are one of 


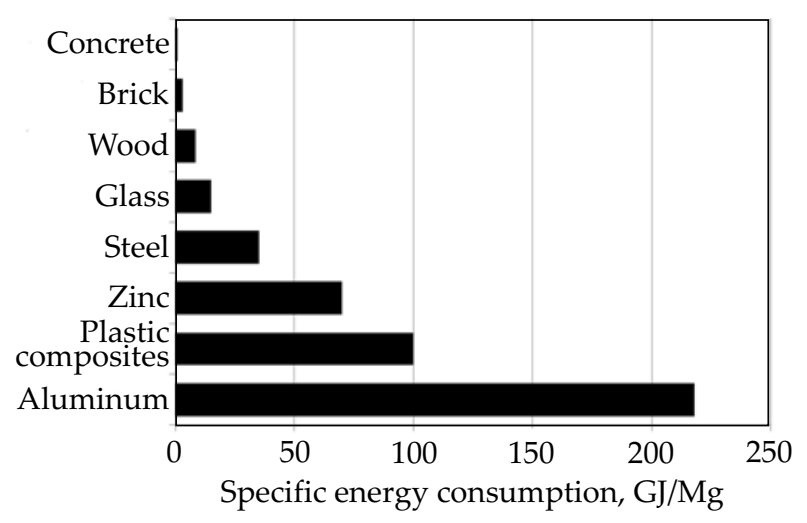

Fig. 1. Approximate amount of energy needed for production of different materials [8]

the most energy-saving materials, taking into account the full life cycle of the products.

Because the injection molding process is one of the most energy-efficient manufacturing processes (per unit volume of material), it might seem that it should not require greater attention from the energetic point of view. However, this is the misleading approach, mainly due to the extremely frequent use of injection molding process in the world, and hence the massive amount of polymeric materials processed with this technique. In order to illustrate how large is the consumption of energy in the area of injection processing on a global scale, it is worth to present some literature data [5, 9-12]. A life cycle inventory (LCI) of injection molding process indicates that the largest energy expenditure is characterized by the first stage of the cycle - the production of the polymeric material. Figure 2 shows the average values of the LCI for injection molding process of a typical large-scale thermoplastics. The value of the LCI for the polymer production stage is also averaged (PE-LD - $73 \mathrm{MJ} / \mathrm{kg}$, PE-HD - $89 \mathrm{MJ} / \mathrm{kg}$, PP - $83 \mathrm{MJ} / \mathrm{kg}$, PS - $87 \mathrm{MJ} / \mathrm{kg}$ ) [9].

Table 1 shows the amount of energy consumed annually in the world by injection molding industry (for LCI, without the polymer production stage - see Fig. 2). In accordance with the recommendations [12] it was assumed that $70 \%$ of injection molding machines used in the world industrial production are hydraulic, $15 \%$ are hybrid and $15 \%$ are full-electric machines. Table 2 shows the annual energy production in 2011 in selected countries of the world. In the last few years, energy production in those countries remained substantially constant.

Comparing the data in Table 1 and Table 2 we can see that the annual energy consumption in injection mold-

T a b l e 1. Total energy used in injection molding, without material production [12]

\begin{tabular}{l|c}
\multicolumn{1}{c|}{ Specification } & $\begin{array}{c}\text { Global } \\
\text { GJ/yr }\end{array}$ \\
\hline 4 Thermoplastics (PE, PP, PS, PVC) & $4.0 \mathrm{E}+8$ \\
All plastics & $6.7 \mathrm{E}+8$ \\
\hline
\end{tabular}

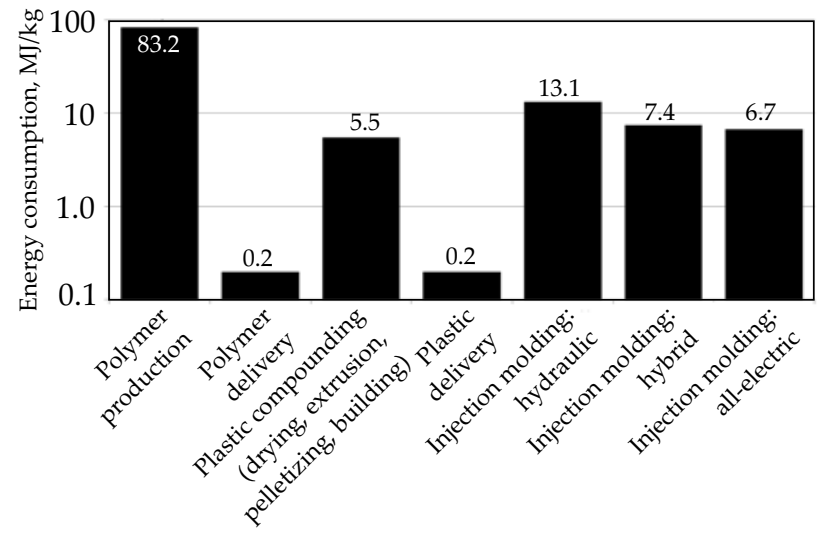

Fig. 2. Energy consumption in LCI for injection molding [12]

ing industry around the world is comparable to the order of magnitude with the annual production of energy in different countries. The amount of energy of approximately $10 \mathrm{E}+8 \mathrm{GJ}$ per year is significant on a national scale. Therefore, the problem of energy consumption in injection molding process of polymeric materials seems to be very important. Appropriate control of injection process can result in considerable energy savings while maintaining the suitable properties of the product.

The aim of this work is the analysis of the specific energy consumption (SEC) in injection molding process for five commonly used thermoplastic polymers: polyethylene low-density, polyethylene high-density, polypropylene, polystyrene, polyoxymethylene (PE-LD, PE-HD, PP, PS, POM, respectively) at various operating parameters of the injection molding process. The study involved only the

T a b l e 2. Annual electricity production in 2011 [13]

\begin{tabular}{l|c}
\hline \multicolumn{1}{c|}{ Country } & $\begin{array}{c}\text { Total electricity net generation } \\
\mathrm{GJ} / \mathrm{yr}\end{array}$ \\
\hline U.S. & $1.5 \mathrm{E}+10$ \\
Germany & $3.0 \mathrm{E}+09$ \\
Italy & $1.0 \mathrm{E}+09$ \\
Spain & $1.0 \mathrm{E}+09$ \\
Australia & $8.6 \mathrm{E}+08$ \\
Turkey & $7.9 \mathrm{E}+08$ \\
Ukraine & $6.6 \mathrm{E}+08$ \\
Poland & $5.5 \mathrm{E}+08$ \\
Sweden & $5.3 \mathrm{E}+08$ \\
Norway & $4.5 \mathrm{E}+08$ \\
Argentina & $4.4 \mathrm{E}+08$ \\
Netherlands & $3.8 \mathrm{E}+08$ \\
Czech Republic & $2.9 \mathrm{E}+08$ \\
Finland & $2.5 \mathrm{E}+08$ \\
Austria & $2.2 \mathrm{E}+08$ \\
Romania & $2.1 \mathrm{E}+08$ \\
Portugal & $1.8 \mathrm{E}+08$ \\
\hline
\end{tabular}


plasticizing system of an injection molding machine. It is known that the power demand during the injection molding process is dominated mainly by the plasticizing system, i.e., by a hydraulic motor of the injection molding machine (working during a reciprocating motion of the screw, around $50 \%$ of the total power demanded during working of the injection machine) and the heating elements of the barrel (approx. $30 \%$ of the total power) [10, 11]. More precise analyses of power demand during various stages of injection cycle are presented in [10-12, 14]. It follows that a phase of plasticization (rotation and reverse movement of the screw) is the most critical stage of the entire injection cycle from the energy consumption point of view. The effect of the screw rotation stage of injection molding process on the entire average energy consumption is even greater for full-electric injection molding machines than for hydraulic ones [12].

This work concerns studies of the impact of most important factors affecting the power demand by the injection molding process. These are power demand by a hydraulic motor (back pressure and rotational speed of the screw) and the heating elements (temperature of the barrel). In the analysis, some less quantifiable factors, such as the energy dissipated in gear system, have been neglected.

\section{EXPERIMENTAL PART}

In order to estimate the specific energy consumption (SEC) during plasticization phase of the injection molding process, first we have to calculate a power demand by the plasticizing zone of injection machine. Then we can calculate the $S E C$ value $(\mathrm{kWh} / \mathrm{kg})$ as a ratio of the power and the mass yield of plasticization from the Formula (1):

$$
S E C=\frac{\bar{P}}{\dot{Q}}
$$

where $\bar{P}$ is the average power demanded by plasticizing system $[\mathrm{kW}]$ and $Q$ is the mass yield of the injection process $[\mathrm{kg} / \mathrm{h}]$.

Measurement of power demanded by the plasticizing system was made on a research position, consisting of suitably instrumented injection molding machine linked to a collecting and processing data module and a computer for imaging and saving data. An injection molding machine Battenfeld Plus 350/70 was used. The research position was described in more detail in [15]. Basic characteristics of the machine are shown in Table 3. Five different thermoplastic polymers used in this study are described in Table 4 . The product obtained in this study is shown in Fig. 3.

The average power $\bar{P}$ demanded by the plasticizing system has been related to the time of one whole injection cycle. It was assumed that the total average power $\bar{P}$ is equal to the ratio of an average energy $\overline{E c}$ consumed by the plasticizing system during one injection cycle to an average cycle time $\overline{t c}$. The energy $\overline{E c}$ consumed by the plasticizing
T a b l e 3. Characteristics of the screw and the injection molding machine, used in experiments

\begin{tabular}{l|c}
\hline Screw diameter, mm & 25 \\
L/D & 17 \\
Length of feed/melting/metering zone, coils & $14 / 4 / 4$ \\
Channel depth in feed/metering zone, mm & $4.1 / 1.9$ \\
Screw pitch, mm & 19 \\
Flight width, mm & 3.7 \\
Max. clamping force, $\mathrm{kN}$ & 350 \\
Max. injection volume, cm ${ }^{3}$ & 49 \\
Max. injection pressure, $\mathrm{MPa}$ & 157.5 \\
\hline
\end{tabular}

T a b l e 4 . The polymers used in experiments

\begin{tabular}{c|c|c}
\hline Polymer & Type & $\begin{array}{c}\text { MFI } \\
\text { g/10 min }\end{array}$ \\
\hline PE-LD & Malen E FABS 23D022 & $2.2(190 / 2.16)$ \\
PE-HD & Hostalen GC 7260 & $8.0(190 / 2.16)$ \\
PP & Moplen HP548R & $23(230 / 2.16)$ \\
PS & Krasten 154 & $10(200 / 5)$ \\
POM & Schulaform 9A & $10(190 / 2.16)$ \\
\hline
\end{tabular}

system during one injection cycle is the sum of an average energy $\overline{E_{h}}$ consumed by heating elements placed on the barrel at the average cycle time $\overline{t c}\left(\overline{E_{h}}=\overline{P_{h}} \cdot \overline{t c}\right)$ and an average energy $\bar{E}_{s}$ consumed by the injection screw during its rotational movement $\left(\overline{E_{s}}=\overline{P_{s}} \cdot \overline{t r}\right)$, where $\overline{t r}$ is an average time of rotation of the screw. So, we can therefore assume:

$$
\bar{P}=\frac{\overline{E c}}{\overline{t c}}=\frac{\overline{P_{h}} \cdot \overline{t c}+\overline{P_{s}} \cdot \overline{t r}}{\overline{t c}}
$$

The power $\overline{P_{h}}(\mathrm{~kW})$ demanded by the heating elements was determined by the precise measurement of switch-on time of each heater (all three heaters are powered in discreet way) during the whole time of the experiment. Data of power demand for each heater were collected in 16-second cycles, as it is presented in Fig. 4. Then instantaneous values of power demand $P_{h}$ for heaters 1-3 were averaged and added together to give the average power demand $\overline{P_{h}}$.

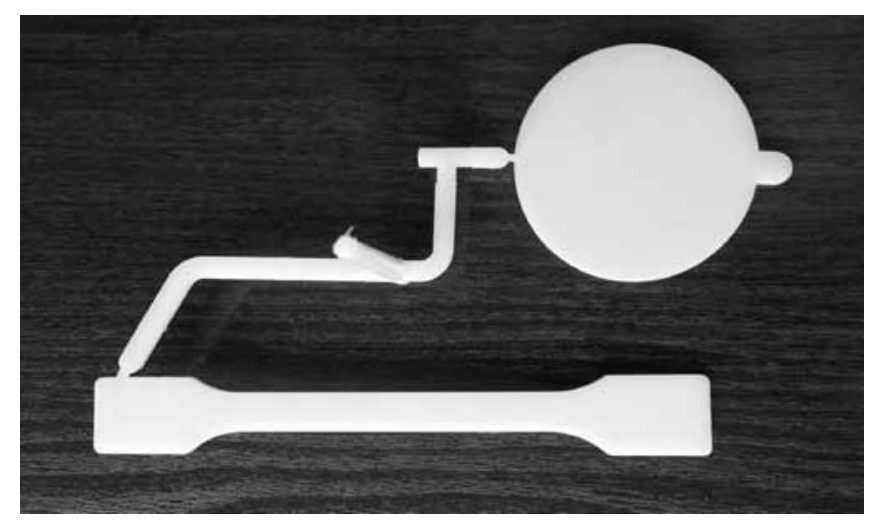

Fig. 3. The element obtained in the study 


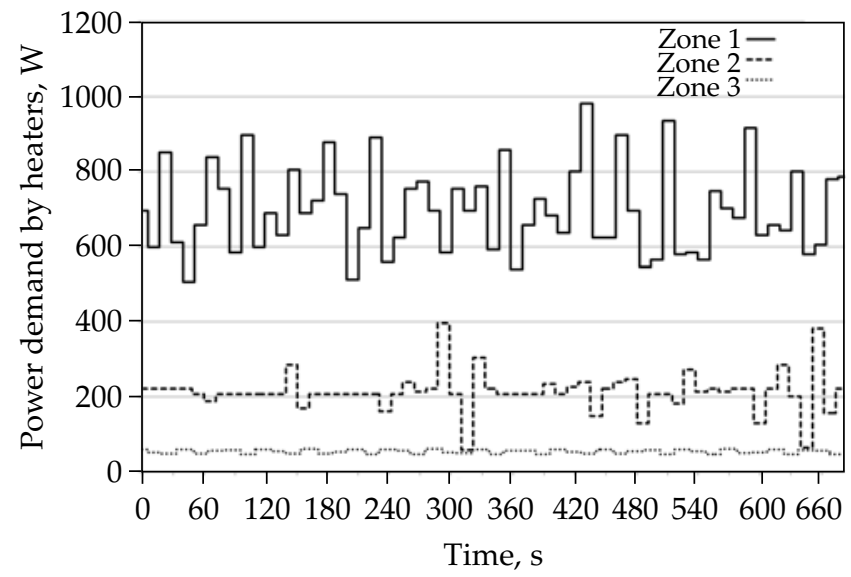

Fig. 4. Sample graph plotting changes of power demand by the barrel's heaters during injection molding of PP

The average power $P_{s}(\mathrm{~kW})$ demanded by the screw during the screw rotation time was determined indirectly by measuring the torque (using the device for measurement of torque, mounted directly on a drive system of screw), which was then converted to power by using the known Formula (3):

$$
\overline{P_{s}}=\frac{\bar{M} \cdot v r}{9550}
$$

where: $\bar{M}$ - an average value of torque on the screw during screw rotational movement $[\mathrm{N} \cdot \mathrm{m}], v r-$ a rotational speed of the screw [rpm].

The average value of torque $\bar{M}$ was calculated as arithmetic averaging of instantaneous values of measured torque $M$. The instantaneous values of torque $M$ during

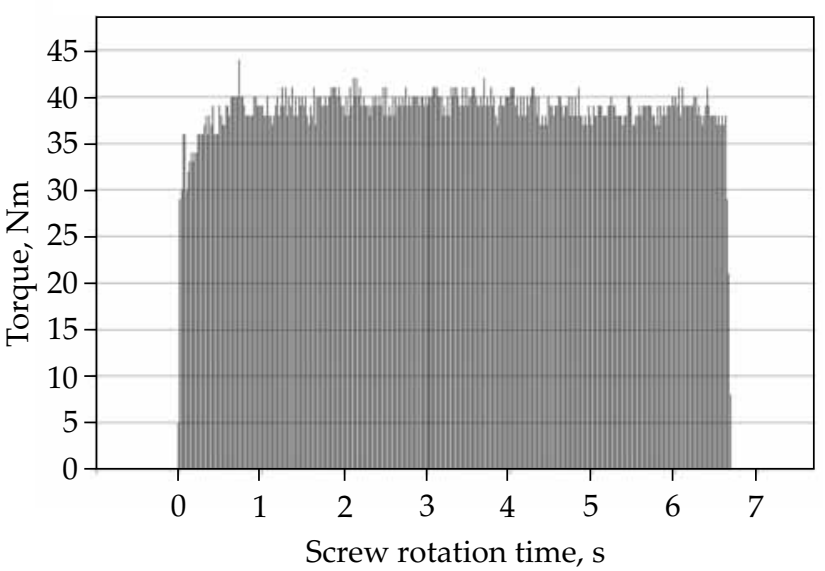

Fig. 5. Sample graph plotting changes of torque during the rotation of the screw during injection molding of PE-HD

the screw rotation movement were slightly changing, as it is shown exemplary in Fig. 5.

Measurements of the torque were performed with a frequency of $50 \mathrm{~Hz}$. The above approach to determining of power demand on the hydraulic motor was made, because other methods (e.g., power demand measurement by assessing the hydraulic pump capacity and its rotational speed or measurement of the power demand by the electric motor, which drives the hydraulic motor) introduce additional errors. In this experiment these errors could be avoided.

The studies of the injection molding process were carried out by varying of selected controllable parameters of the plasticization process in a relative wide range, as shown in Table 5.

$\mathrm{T}$ a b l e 5. Values of controllable operating parameters of plasticization process

\begin{tabular}{|c|c|c|c|c|c|}
\hline \multirow[b]{2}{*}{ PE-LD, PE-HD, PP, POM, PS } & \multicolumn{5}{|c|}{ Back pressure $p b, \mathrm{MPa}$} \\
\hline & 4 & 7 & 10 & 16 & 24 \\
\hline & \multicolumn{5}{|c|}{ Screw rotation velocity $v r, \mathrm{rpm}$} \\
\hline \multirow[t]{2}{*}{ PE-LD, PE-HD, PP, POM } & 154 & 200 & 240 & 286 & 333 \\
\hline & \multicolumn{5}{|c|}{ Dwell time $t d, \mathrm{~s}$} \\
\hline \multirow[t]{2}{*}{ PE-HD, PE-LD, PP, POM, PS } & 8 & 12 & 20 & 30 & 50 \\
\hline & \multicolumn{5}{|c|}{ Barrel temperature $\mathrm{Tb},{ }^{\circ} \mathrm{C}$} \\
\hline PE-LD & 140 & 160 & 180 & 200 & 220 \\
\hline PE-HD & 150 & 170 & 190 & 210 & 230 \\
\hline PP & 200 & 215 & 230 & 245 & 260 \\
\hline PS & - & 180 & 200 & 220 & 240 \\
\hline
\end{tabular}

$\mathrm{T}$ a b 1 e 6 . Values of invariable operating parameters of the injection process

\begin{tabular}{l|c|c|c|c|c}
\hline & PE-LD & PE-HD & PP & PS & POM \\
\hline Mold temperature, $^{\circ} \mathrm{C}$ & 35 & 35 & 40 & 40 & 75 \\
Hopper zone temperature, ${ }^{\circ} \mathrm{C}$ & 40 & 40 & 40 & 40 & 40 \\
Injection pressure, $\mathrm{MPa}$ & 70 & 80 & 63 & 86 & 70 \\
Holding pressure, $\mathrm{MPa}$ & 40 & 42 & 34 & 28 & 35 \\
Holding time, s & 4 & 4 & 4 & 2.5 & 4 \\
\hline
\end{tabular}


If one parameter was varied, the other parameters were kept constant, with value equal to the middle (third) of five ones listed in Table 5. For example, for changing the back pressure ( $p b-$ a counterpressure, the pressure on the forehead of the screw during its reciprocating movement, [MPa]) parameter during the injection process of PP polymer, the other parameters had constant values equal $v r=240 \mathrm{rpm}, t d=20 \mathrm{~s}$ and $\mathrm{Tb}=230^{\circ} \mathrm{C}$. Other invariable parameters of the injection process are presented in Table 6 .

No tests for POM at variable barrel temperature were carried out because of a narrow processing window for this polymer [16]. Moreover, tests for PS at variable screw velocity were also not carried out for technical reasons. The viscosity of melted PS was high and overload of the screw drive system had occurred at higher values of screw velocity.

The experiment was performed by setting the appropriate values of the operating parameters on the injection molding machine. Then the injection process was started. Once the operating parameters have been established (after reaching the quasi-equilibrium state, i.e., obtaining the constant output parameters at the same moments of the injection cycle - this took about 5 minutes), the measurement system was started and the measurement data were collected for about 10 minutes. Next the working parameters were changed, the operator was waiting for 5 minutes to reach the quasi-equilibrium state and the data collection process was repeated.

Measurement data were collected with the frequency of $50 \mathrm{~Hz}$. Since the measurement took about 10 minutes, the amount of data collected was very large for one measurement and it was about 10-30 thousand for each parameter. Usually, the result graphs should contain scat-
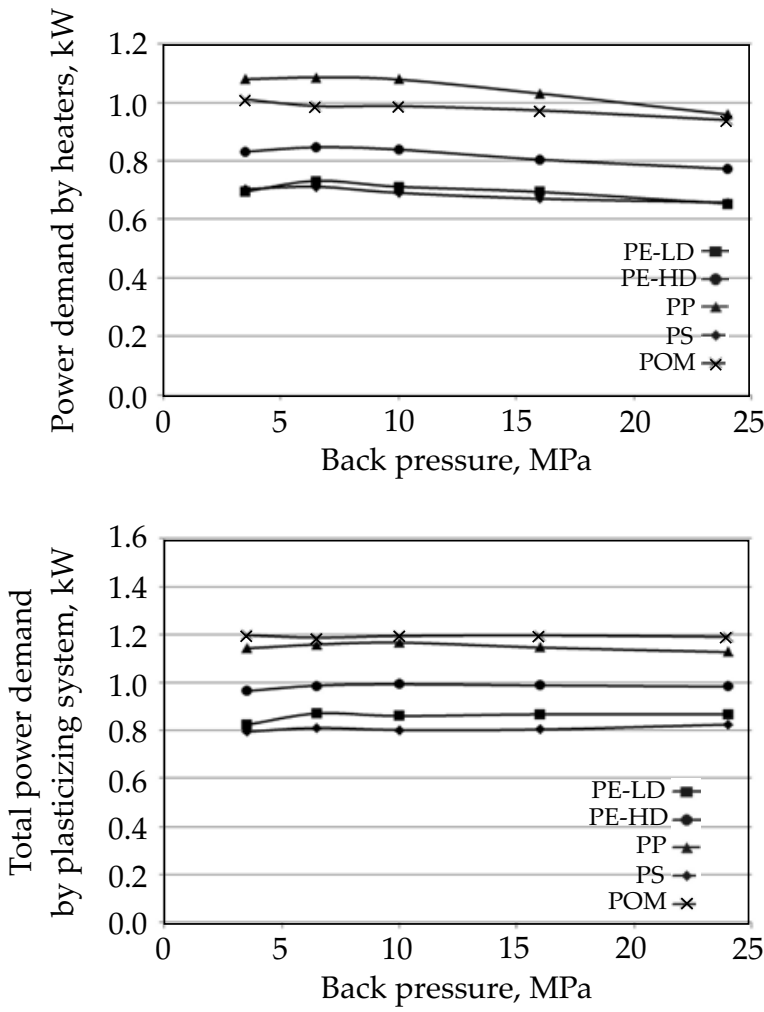

ters that indicate the magnitude of the standard deviation of the mean value $\bar{s}_{\bar{x}}$. However, with a large number of collected data, the standard deviation of the mean value $\bar{s}_{\bar{x}}$ calculated from the Formula (4) (considering the very large value of $n$ parameter) is so small, that the scatters practically overlap with the measurement points on the graph and therefore are not presented:

$$
\bar{s}_{\bar{x}}=\sqrt{\frac{\sum_{i=1}^{n}\left(x_{i}-\bar{x}\right)^{2}}{n(n-1)}}
$$

where: $x_{i}$ - value of $i$-measurement, $\bar{x}$ - average value of $x$ for the entire measurement series, $n$-number of measurements in series.

The aim of this study was an experimental analysis of possible changes in specific energy consumption (SEC) of the plasticizing system in the injection molding machine according to basic control parameters of the plasticization process, i.e., back pressure, screw rotation velocity, time of static melting (dwell time), and average temperature of the barrel. It is relevant for creating and verification of simulation models for the plasticization process, taking into account the widest possible range of changes in regulated process parameters. Such approach, adopted in this study, represents a significant difference compared to the typical plasticizing process optimization, i.e., such selection of parameters, which results in minimizing energy consumption while maintaining good processability of polymers and favorable physical and mechanical characteristics of product. Thus, this work consciously abandons known methods of planning of experiment, for example regression methods with
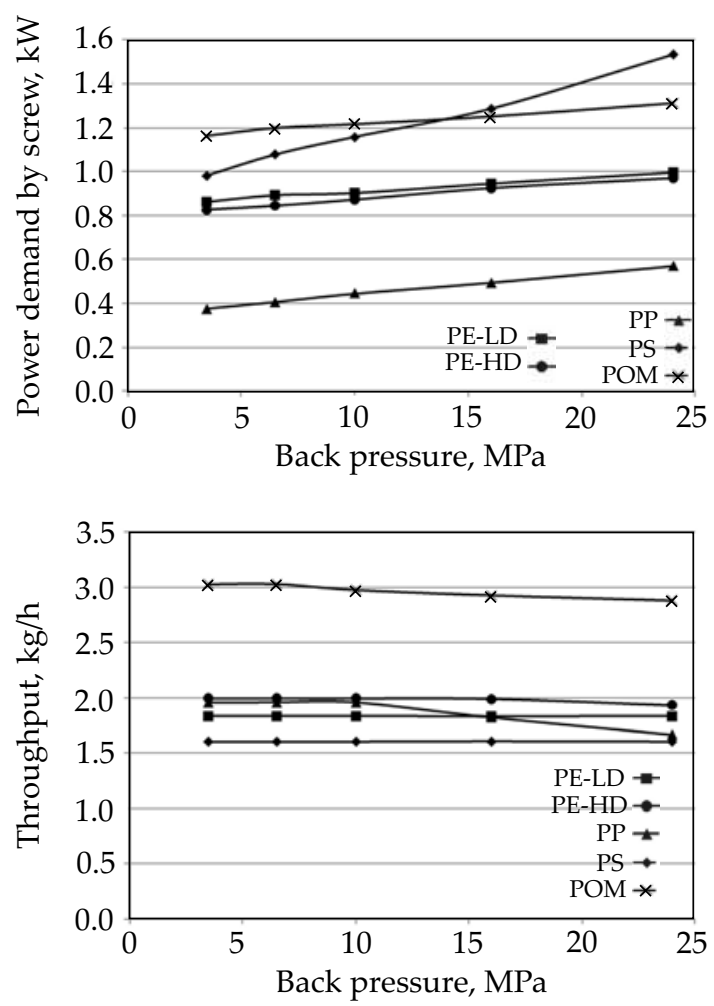

Fig. 6. Power demand and throughput at variable back pressure 


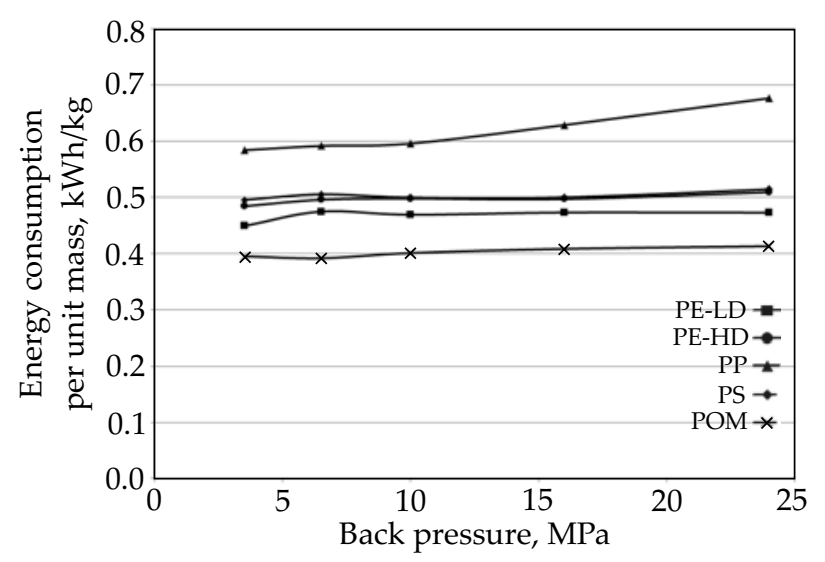

Fig. 7. SEC in injection molding process at variable back pressure

polynomials in a limited range of parameters. In this case, these parameters were deliberately chosen from the range beyond the typical range of processing parameters, resigning from the assessment of physical and mechanical properties of the product, except of the visual evaluation of the correctness of forming process. Because of the large amount of experimental data, mentioned optimization problems will be a content of a separate article. It is worth mentioning, however, that this scheduled study fulfills the requirement for a minimum number of independent experiments.

\section{RESULTS AND DISCUSSION}

Four series of experiments were performed: the first group of experiments took into account variable back pressure, the second one was for variable screw speed,
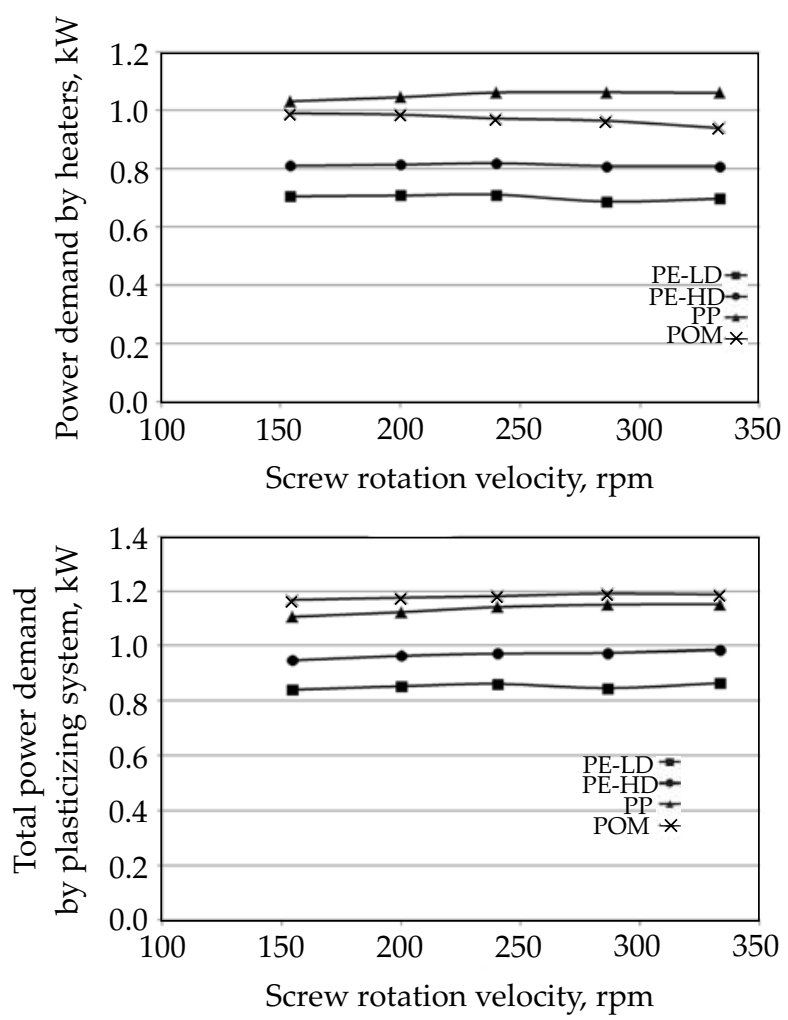

the third one was for variable dwell time and the last one was for variable barrel temperature.

\section{Results at variable back pressure}

In the first series, the average power demanded by the heaters placed on the barrel and the average power demanded by the rotating screw for variable back pressure during plasticization of different thermoplastic polymers were determined. Obtained results, along with the throughput of the injection molding process, are shown in Fig. 6. The SEC values for the injection process of different polymers, defined accordingly to the Formula (1), are shown in Fig. 7.

Figure 6 shows very similar behavior for all tested thermoplastics. By changing back pressure values in the range of 3.5-24.0 MPa, slight maximum of the power demand by the heaters and slight increase of the average power demand by the screw can be observed. Only for amorphous PS, the power demand by the screw increases quite rapidly with increasing back pressure. Assuming that there are two most important power components mentioned above, i.e., the average power demanded by the screw and the average power demanded by the heaters, the approximate total power demanded by the plasticizing system of injection molding machine does not practically change with increasing back pressure. On the other hand, due to the constant throughput of the injection molding process for the whole range of back pressure values, it can be seen in Fig. 7, that the SEC remains constant with the exception of $\mathrm{PP}$, where the SEC grows about $20 \%$ for back pressure changes in the range of
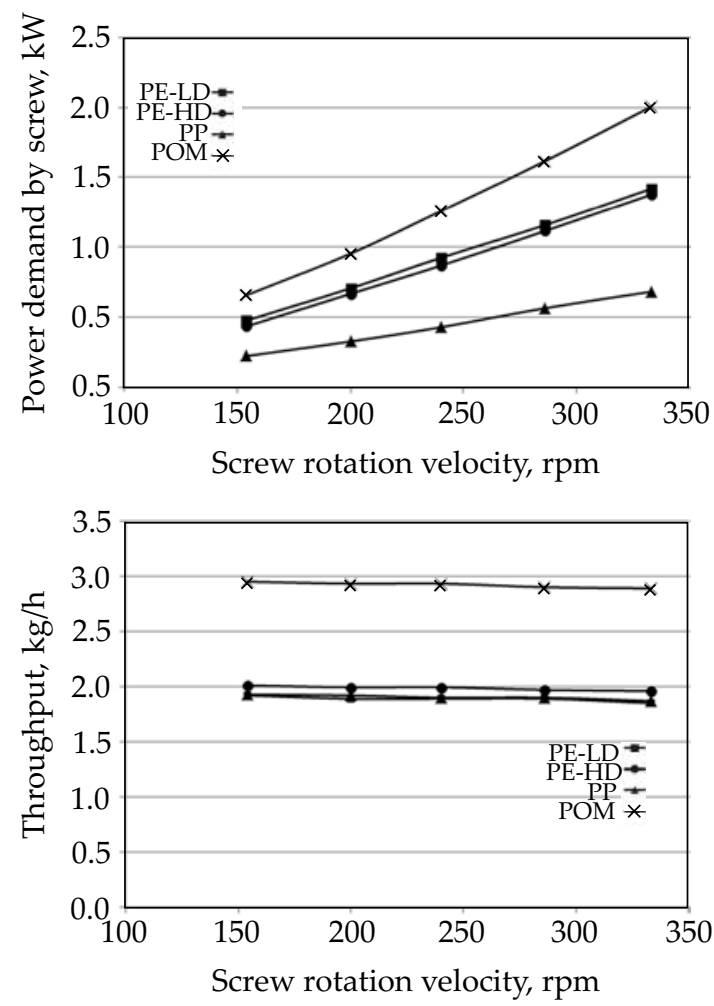

Fig. 8. Power demand and throughput at variable screw rotation velocity 


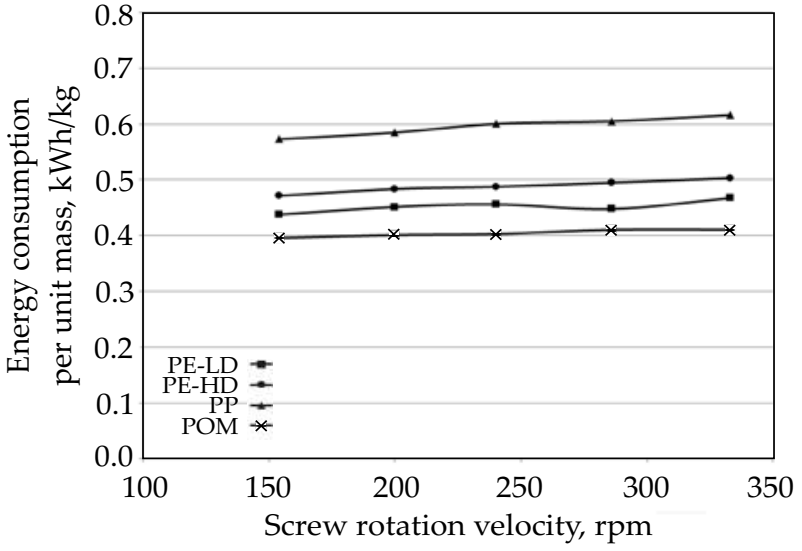

Fig. 9. SEC in injection molding process at variable screw rotation velocity

3.5-24.0 MPa as a result of throughput decreasing. However, the different behavior of PP may be associated with the different melting mechanism. It could be related to high degree of crystallinity of solid PP and/or with crystals rearrangement during fusion $[17,18]$. The different behavior of PP during the melting process could be also observed in work concerned with starve feeding in extrusion process [19].

The results show that the injection molding process on the research position should be performed at the higher back pressure values, because on the one hand, it promotes improvement of material and thermal homogenization of molten polymer in the barrel. On the other hand, the increase in back pressure does not practically affect throughput and power demand by the plasticizing system, that is crucial in the entire LCI for the injection molding process.
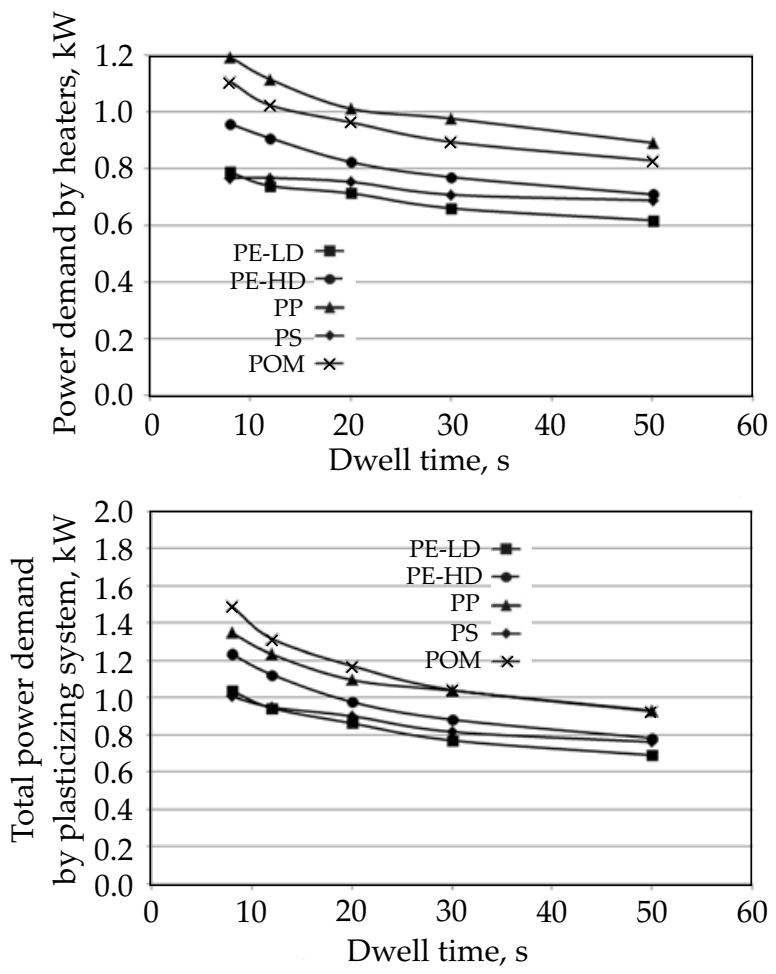

Fig. 10. Power demand and throughput at variable dwell time

\section{Results at variable rotational velocity of the screw}

The next experiment involved measurements of characteristics of the injection molding process at variable screw rotation velocity. Measurement results of power characteristics and process yield are shown in Fig. 8. The $S E C$ for the injection molding process for various thermoplastic polymers at different values of screw rotation speed is shown in Fig. 9.

There is practically no impact of variable rotational velocity of the screw on the power demand by heating elements (Fig. 8) for all investigated polymers. At the same time, a significant increase of the average power demand by the screw can be seen. This leads to a mild growth of the total power demand by the plasticizing system with increasing rotational velocity of the screw, regardless of the type of polymer. Because of the constant yield characteristics (the rotation time of the screw is a part of the cooling time and has no impact on the yield of the injection molding process) with rising screw velocity, it can be seen in Fig. 9 that the SEC increases very slightly. It follows that the injection molding process should be carried out at the low to medium values of the rotational screw velocity. High values of the screw speed result in the increased SEC till approx. $10 \%$ for the highest screw speed. Of course, the increasing power demand values by the screw for increasing rotational speed are compensated by the decreasing rotation time of the screw. It is the result of the $\left(\overline{P_{s}} \cdot \overline{t r}\right)$ term in formula (2). Hence, the effect of the power demanded by the screw on the $S E C$ is very small.

In conclusion, lower screw velocity values give less power demand by plasticizing process and, due to the constant
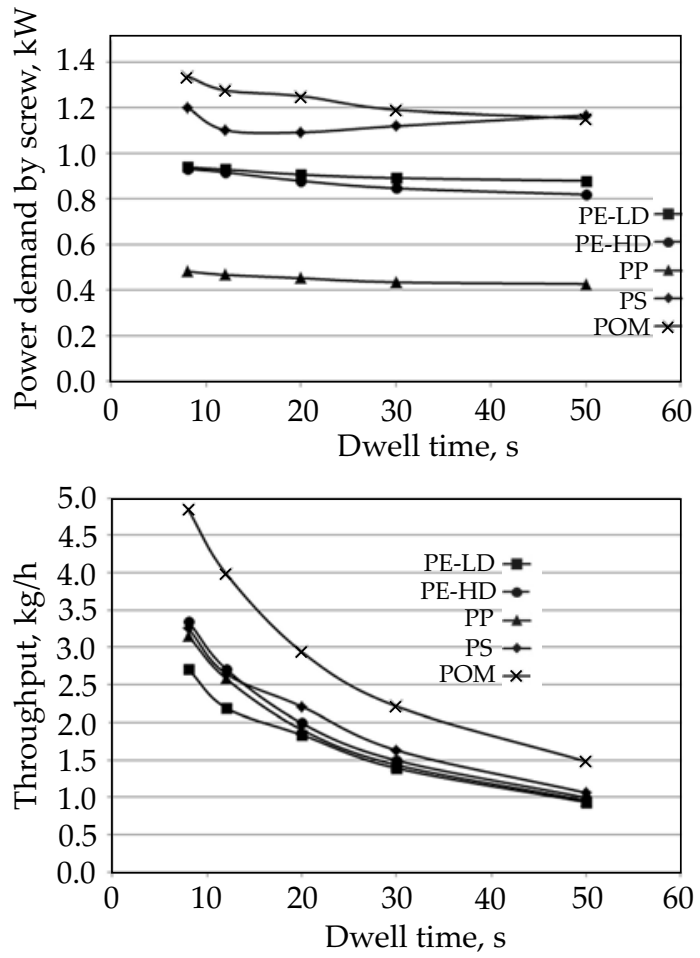


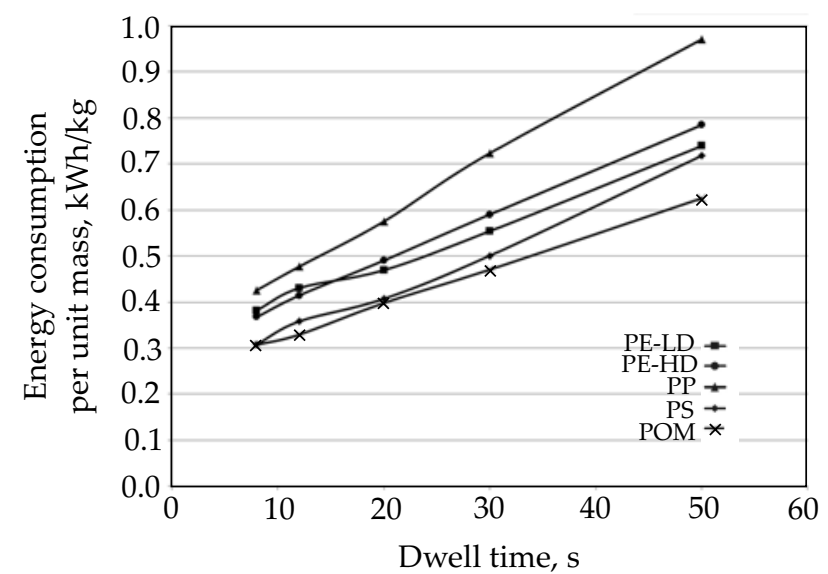

Fig. 11. SEC in injection molding process at variable dwell time

throughput values, lower $S E C$ values. These differences in the SEC values, however, are very small. At the same time it is worth noting that it is not recommended to perform the injection molding process with high values of the rotational velocity of the screw. In this case, the circumferential speed is rather more important than the rotational one. With the large circumferential speed, a probability of a thermal decomposition of some polymer materials grows especially for the processing of more thermally sensitive materials such as PVC, polymer blends, thermosets, and elastomers [20].

\section{Results at variable dwell time}

In the next experiment a dwell time, considered as a time between the end of the screw rotation and the beginning of the injection phase, was changed. Measure-
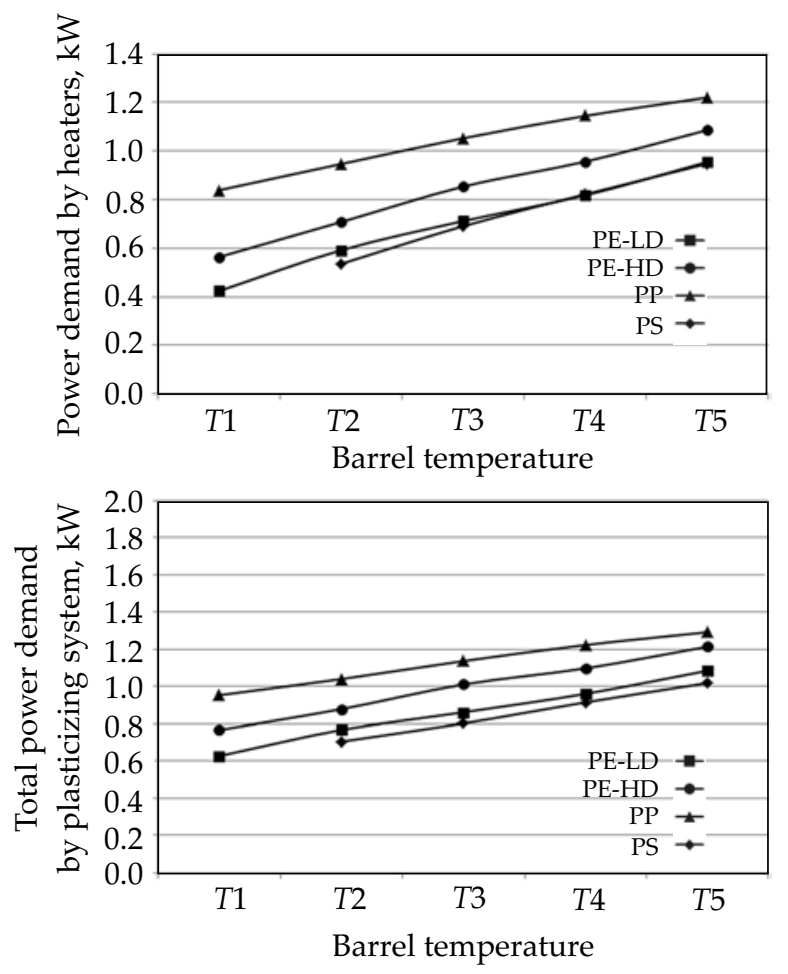

ment results of energy performance for changing dwell time in the range of $8-50 \mathrm{~s}$ are presented in Fig. 10. It can be seen that the dependence of power demand by heaters decreases slightly in an almost linear way. The lowering of the power demand by the heating elements for the range of dwell time of $8-50 \mathrm{~s}$ is approx. $25-30 \%$. Slight asymptotic decrease in the power demanded by the screw with the increasing dwell time is associated with the longer cycle time. It gives an increasing importance of static melting and, as a consequence, increasing temperature of molten polymer and decreasing of polymer viscosity. Such behavior gives, as a result, an asymptotic decrease of the total power demand by all thermoplastics, which is equal roughly to $0.3-0.5 \mathrm{~kW}$ for the range of dwell time of 8-50 s. At the same time, the yield of the injection molding process strongly decreases asymptotically with the rise of dwell time, which is related to the significant increase in the cycle time. Hence, the SEC for the increasing dwell time grows significantly in a linear way, as shown in Fig. 11.

\section{Results at variable temperature of the barrel}

The last study included measurements of the injection molding characteristics at variable barrel temperature. The temperature values $T 1-T 5$ were different for each polymer used and they were changed in accordance with data shown in Table 5. The temperature values were the same for all heating zones due to assumptions about the change in barrel temperature. It did not have a significant effect on the quality of the moldings. Measurements results of the power demand, the yield of the injection
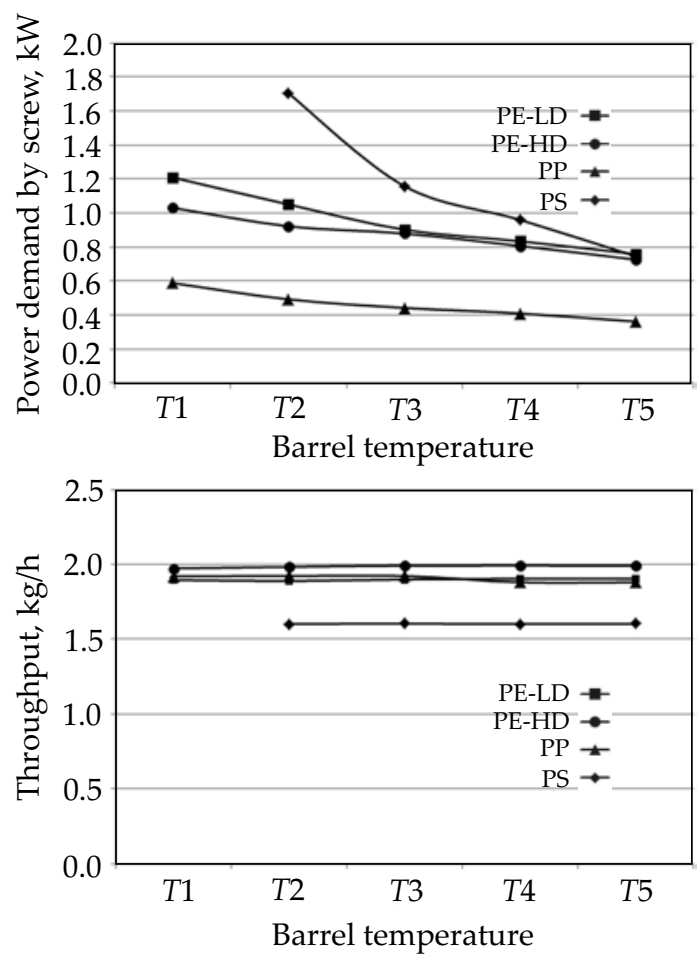

Fig. 12. Power demand and throughput at variable barrel temperature 
T a b l e 7. Measured MFI values of polymers at minimum and maximum processing temperature

\begin{tabular}{c|c|c|c}
\hline & PE-LD & PE-HD & PS \\
\hline MFI at min. temp., g/10 min & 0.6 & 2.0 & 11.7 \\
MFI at max. temp., g/10 min & 4.0 & 12.0 & 33.4 \\
\hline
\end{tabular}

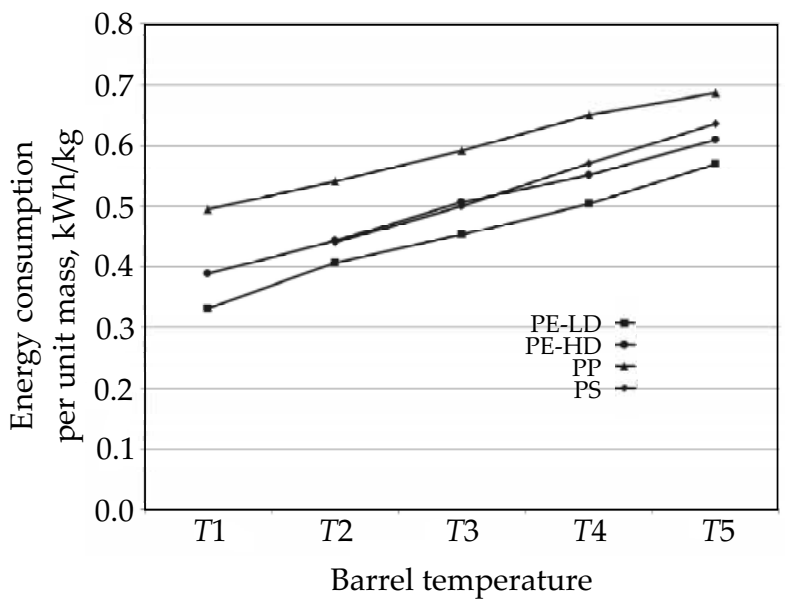

Fig. 13. SEC in injection molding process at variable barrel temperature

molding process and the SEC are presented in Figs. 12 and 13.

The power demand by the heating elements mounted on the barrel grows expectedly in a linear way along with linearly increasing temperature, while the average power demand by the screw decreases linearly probably as a result of the drop in the viscosity of molten polymers. This can be seen particularly in the case of amorphous PS. It is shown in the Table 7, where measured MFI values (under the load $m=2.16 \mathrm{~kg}$ ) for the minimum and maximum processing temperature of polymers are given. We can see that the MFI in the whole range of processing temperature increases most for PS.

However, changes in the power demand by the rotating screw are clearly smaller than rise in the power demand by the heaters because of increasing barrel temperature. Hence, the rise of the total power demand by the plasticizing system in the amount of about 15-20\% can be observed with the rise of the barrel temperature by $20^{\circ} \mathrm{C}$. Because there is no discernible effect of the barrel temperature on the yield of the injection process, the $S E C$ values for the injection of thermoplastics with variable barrel temperature show the increase similar to the increase of the total power demand.

\section{CONCLUSIONS}

The injection molding process is a very widespread method of polymer processing, for which the annual, global energy consumption is comparable to the annual energy production of different European countries. The most energy-consuming stage is the plasticization process which needs the energy for reciprocating screw motion and heating of the barrel. In this work both the issues were examined by changing various working parameters of the injection molding process, measuring the corresponding process characteristics and calculating relevant values of the specific energy consumption. Five thermoplastic polymers (PE-LD, PE-HD, PP, PS and POM) were examined. It was found that the optimal conditions to perform the plasticization of thermoplastic polymers on the research position [15] were obtained when the low rotational screw velocity was applied. An increase of the $S E C$ value with increasing barrel temperature was shown. It was $c a .15 \%$ for the barrel temperature rise by $20{ }^{\circ} \mathrm{C}$. It was also found that back pressure changes do not affect the power demand by the plasticizing system of the injection molding machine.

The strength measurements were not performed in this study. We focused only on power demand. The range of variable process parameters was assumed to obtain the correct quality of the moldings without shrinkage and other visible defects. It is worth to compile the proposed directions of changes in the values of technological parameters of the injection molding process with the mechanical properties of the received products. Then we can make a full analysis of the profitability of changes of technological parameters mentioned above.

Summarizing, it has been shown that the process of injection molding for thermoplastics should be performed at relatively low values of screw rotational velocity and large values of back pressure, as well as short values of dwell time for minimizing the energy consumption under the above experimental conditions. It is worth to perform similar research for larger injection molding machines and geometrically various moldings to generalize or detail the results presented in this work.

\section{REFERENCES}

[1] Davim P.: "Sustainable Manufacturing", ISTE, London, 2010.

[2] Herrmann C., Hauschild M., Gutowski T.G., Lifset R.: Journal of Industrial Ecology 2014, 18, 471. http://dx.doi.org/10.1111/jiec.12177

[3] Allwood J.M., Ashby M.F., Gutowski T.G., Worrell E.: Philosophical Transactions of the Royal Society A 2013, 371, 20120496. http://dx.doi.org/10.1098/rsta.2012.0496

[4] Gutowski T.G., Sahni S., Allwood J.M. et al.: Philosophical Transactions of the Royal Society A 2013, 37, 20120003.

http://dx.doi.org/10.1098/rsta.2012.0003

[5] "Re-engineering Manufacturing for Sustainability" Proceedings of the $20^{\text {th }}$ CIRP International Confer- 
ence on Life Cycle Engineering" (Eds. Nee A.Y.C., Song B., Ong S.K.), Springer, Berlin 2013.

[6] Kent R.: Plastics, Rubber and Composites 2008, 37, 96. http://dx.doi.org/10.1179/174328908X283285

[7] Kent R.: “Energy Management in Plastic Processing, A Signposting Guide by The British Plastics Federation", BPF Energy, London 2011.

[8] Materials from NANOCEM website: "The IndustrialAcademic Nanoscience Research Network for Sustainable Cement and Concrete".

[9] Gutowski T.G., Dahmus J., Thiriez A.: "Electrical Energy Requirements for Manufacturing Processes", $13^{\text {th }}$ CIRP International Conference on Life Cycle Engineering, Leuven, May 31 ${ }^{\text {st }}$-June $2^{\text {nd }}, 2006$.

[10] Qureshi F., Li W., Kara S., Herrmann Ch.: "Leveraging Technology for a Sustainable World" (Eds. Dornfeld D., Linke B.), Springer, Berlin 2012, pp. 269-274.

[11] Ribeiro I., Peças P., Henriques E.: "Leveraging Technology for a Sustainable World" (Eds. Dornfeld D., Linke B.), Springer, Berlin 2012, pp. 263-268.

[12] Thiriez A., Gutowski T.: "An environmental analysis of injection molding", Electronics and the Environment: Proceedings of the 2006 IEEE International Symposium, Scottsdale, AZ, USA, 8-11 May 2006. http://dx.doi.org/10.1109/ISEE.2006.1650060
[13] Energy Information Administration, www.eia.gov (access date 15.11.2015)

[14] Park H.S., Nguyen T.T.: Journal of Computational Design and Engineering 2014, 1, 256. http://dx.doi.org/10.7315/JCDE.2014.025

[15] Iwko J., Steller R., Wroblewski R.: Polymer Processing 2015, 1, 15.

[16] Technical Datasheet for Schulaform 9A Acetal Copolymer: http://www.aschulman.com/Asia-Pacific/Engineered-Plastics/Products/40/1913/SCHULAFORM. aspx (access date 21.01.2016)

[17] Guerra G., Petraccone V., Corradini P. et al.: Journal of Polymer Science Part B Polymer Physics 1984, 22, 1029. http://dx.doi.org/10.1002/pol.1984.180220608

[18] Tiganis B.E., Shanks R.A., Long Y.: Journal of Applied Polymer Science 1996, 59, 663.

h t t p://dx.doi.org / 10.1002 / ( S I C I) 1097 4628(19960124)59:4<663::AID-APP12>3.0.CO;2-R

[19] Wilczynski K.J., Nastaj A., Lewandowski A., Wilczynski K.: Polymer Engineering and Science 2014, 54, 2362. http://dx.doi.org/10.1002/pen.23797

[20] Johannaber F.: "Injection Molding Machines: a User's Guide", Munich, Germany 2008.

Received 20 VII 2017.

\section{W kolejnym zeszycie ukażą się m.in. następujące artykuły:}

S. Firlik, J. Stasiński, S. Pawłowski - Wpływ budowy układu katalitycznego i warunków polimeryzacji utleniającej 2,6-dimetylofenolu na wydajność i masę molową poli(tlenku fenylenu)

E. Jamróz, A. Konieczna-Molenda, A. Para-Otrzymywanie i charakterystyka binarnych kompleksów furcellaranu z żelatyną i albuminą surowicy bydlęcej (j. ang.)

X. Yang, J. Wang, T. Song, Z. Li, J. Hao - Samogasnąca nitroceluloza o małej zawartości azotu z dodatkiem synergicznie działających dimetylofosfonianu metylu i długołańcuchowej chlorowanej parafiny (j. ang.)

M. Alkateb, M.S. Sapuan, Z. Leman, M. Jawaid, M.R. Ishak - Wytrzymałość na zgniatanie rur eliptycznych $\mathrm{z}$ „zielonych” kompozytów epoksydowych wzmacnianych włóknami kenafu i prętami drewnianymi ( $j$. ang.)

A. Lewandowski, K. Wilczyński - Uogólniony model uplastyczniania tworzyw polimerowych w procesie wytłaczania

\section{Komunikaty szybkiego druku}

P. Staciwa, T. Spychaj - Nowe ciecze głęboko eutektyczne na podstawie amin aromatycznych do sieciowania żywicy epoksydowej (j. ang.)

A. Frańczak, M. Oleksy, R. Oliwa, G. Budzik-Kompozyty polietylenowe uniepalnione wodorotlenkiem glinu stosowane na powłoki kabli elektrycznych (j. ang.) 